\title{
RADIOCARBON RELEASES AT THE KRŠKO NUCLEAR POWER PLANT
}

\author{
BARBARA VOKAL $L^{1}$ and IVAN KOBAL $L^{1,2}$
}

\begin{abstract}
Since 1991, radiocarbon analyses of exhaust air have been part of the regular radioactivity monitoring program at the Krško Nuclear Power Plant (NPP), a Westinghouse $632 \mathrm{MWe}$ pressurized water reactor (PWR). Activity of $\mathrm{CO}_{2}$ and hydrocarbons has been identified; the former contributes $c a$. $43 \%$. A normalized release of total ${ }^{14} \mathrm{C}$ of $0.219 \mathrm{TBqGWe}^{-1} \mathrm{a}^{-1}$ was obtained. Indoor air ${ }^{14} \mathrm{C}$ concentrations in selected rooms inside the plant have generally been $<5 \mathrm{~Bq} \mathrm{~m}^{-3}$, although rare peaks of $>1000 \mathrm{~Bq} \mathrm{~m}^{-3}$ may be reached. Tree rings have shown slight enhanced ${ }^{14} \mathrm{C}$ activity due to the operation of the plant.
\end{abstract}

\section{INTRODUCTION}

The presence of radiocarbon (half-life $5730 \pm 40 \mathrm{yr}$, maximum beta energy of $162 \mathrm{keV}$ ) in our environment is due to three production pathways (Raaen, Ropp and Raaen 1968): nuclear reactions induced by cosmic rays in the upper atmosphere, nuclear weapons testing, and the nuclear fuel cycle including nuclear power plants. The total ${ }^{14} \mathrm{C}$ activity on the Earth is estimated to amount to $83 \times 10^{8}$ GBq (Fairhall and Young 1970) and is distributed among the hydrosphere, biosphere and atmosphere, the latter contribution being $1.6 \times 10^{8} \mathrm{GBq}$ in the $\mathrm{CO}_{2}$ form, resulting in an air concentration of $42.4 \mathrm{mBq} \mathrm{m}^{-3}$. This is only $1.9 \%$ of the total ${ }^{14} \mathrm{C}$ as compared with $94.3 \%$ in the oceans.

The changes in ${ }^{14} \mathrm{C}$ content in the environment result from two opposing anthropogenic activities: 1) The Suess effect (Fairhall and Young 1970), caused by combustion of fossil fuel low in ${ }^{14} \mathrm{C}$, and 2) an enhancement due to nuclear reactors and nuclear weapons testing. Thus, the industrial revolution first decreased its content and then nuclear weapons testing increased it. After weapons testing ceased, the content started to decrease (Levin, Münnich and Weiss 1980; Csongor and Hertelendi 1982; Levin et al. 1988; Hertelendi and Csongor 1982). The Suess effect may also explain the periodic ${ }^{14} \mathrm{C}$ depletions in the air of heavily industrialized urban areas during warm seasons (Csongor and Hertelendi 1982; Segl et al. 1983; Belan et al. 1990). According to some estimates, the total ${ }^{14} \mathrm{C}$ enhancement due to the nuclear industry in the years 1975-2000 will be $10 \%$ of that from nuclear weapons testing and only $0.3 \%$ of the natural inventory (Hayes and MacMurdo 1977). On the other hand, the "pessimistic" scenario predicts that releases from the nuclear fuel cycle will exceed natural production after 2000 (Otlet, Fulker and Walker 1992). Because of their ease of incorporation into the global carbon cycle and their long half-life, these releases should be considered very carefully in estimating their local and global effect on the collective dose commitments (McCartney, Baxter and McKay 1986; McCartney, Baxter and Scott 1988a; McCartney, Baxter and Scott 1988b).

In a light-water nuclear reactor, ${ }^{14} \mathrm{C}$ is produced by neutron activation according to the reactions ${ }^{17} \mathrm{O}(\mathrm{n}, \alpha){ }^{14} \mathrm{C}$ with oxygen in oxides of fuel, moderator and coolant, and ${ }^{14} \mathrm{~N}(\mathrm{n}, \mathrm{p}){ }^{14} \mathrm{C}$ with nitrogen as impurities in fuel, moderator and coolant (Wallace 1979). For the pressurized water reactor (PWR) type reactors, the ${ }^{14} \mathrm{C}$ production rates of $0.57,0.97$, and $0.19 \mathrm{TBq} \mathrm{GWe}^{-1} \mathrm{a}^{-1}$ in the fuel, construction material, and coolant, respectively, are estimated (Wallace 1979; Hertelendi et al. 1989). More than $95 \%$ of the ${ }^{14} \mathrm{C}$ produced is released in a gaseous form through the stack of a nuclear power plant (NPP) (Kunz 1985), mainly in $\mathrm{CO}_{2}$ form (Wahlen and Kunz 1978; Winkelmann, Gesewsky and Schwibach 1984), though the $\mathrm{CO}_{2}$ /hydrocarbons ratio may substantially differ for PWR reactors (Hertelendi, Uchrin and Ormai 1989; Uchrin et al. 1992).

${ }^{1} \mathrm{~J}$. Stefan Institute, Jamova 39, P.O.B. 3000, 1001 Ljubljana, Slovenia

${ }^{2}$ School of Environmental Sciences, Vipavska 13, P.O.B. 301, 5000 Nova Gorica, Slovenia 


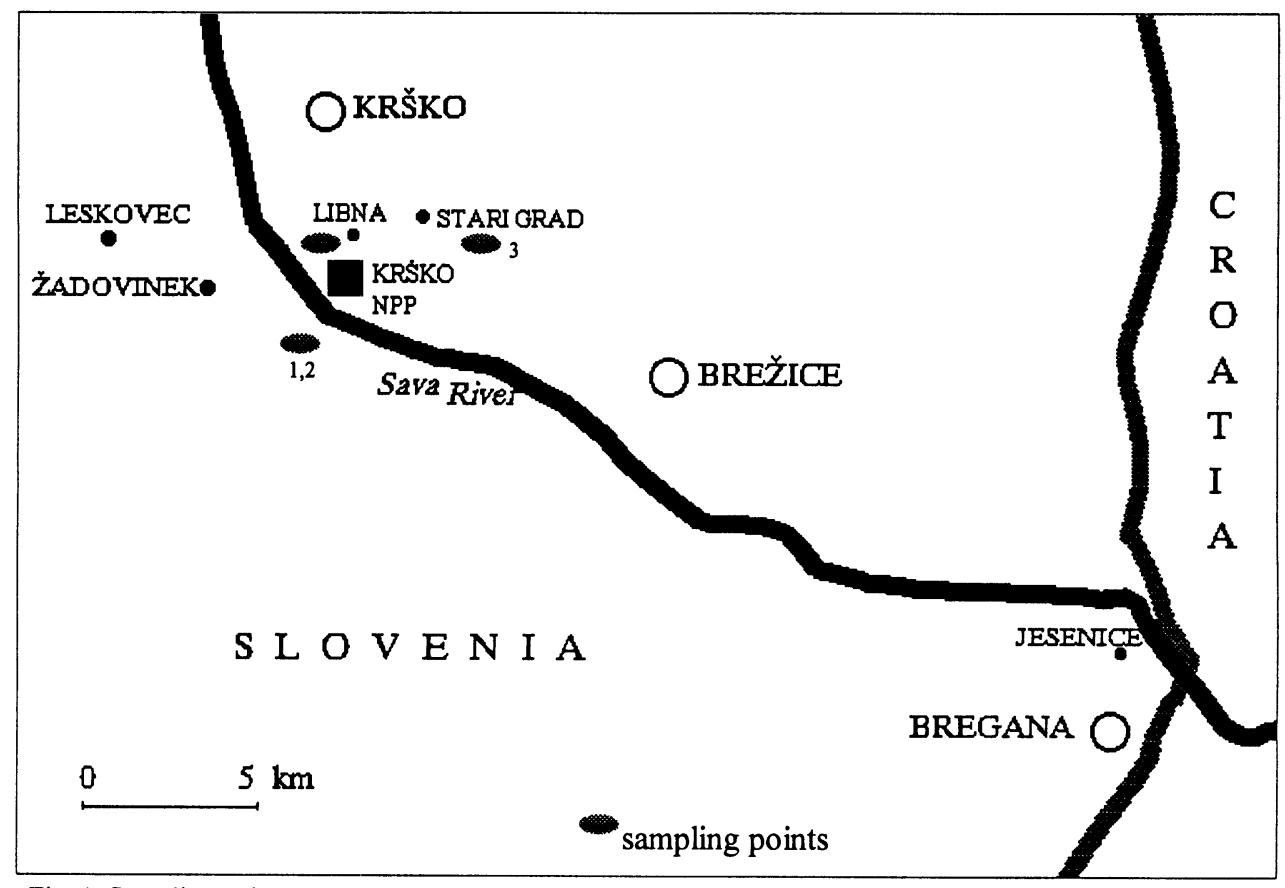

Fig. 1. Sampling points

The Krško Nuclear Power Plant is a PWR Westinghouse 632 MWe reactor, situated (Fig. 1) on the left bank of the Sava River $\left(45^{\circ} 45^{\prime} 15^{\prime \prime} \mathrm{N}, 15^{\circ} 31^{\prime} 14^{\prime \prime} \mathrm{E}\right)$, close to the border between Slovenia and Croatia, $c a .100 \mathrm{~km}$ downstream from the Slovenian capital Ljubljana with 370,000 inhabitants, and about $30 \mathrm{~km}$ upstream from the Croatian capital Zagreb with about a million inhabitants. Its operation started in 1983.

The first ${ }^{14} \mathrm{C}$ measurements in air, water and plants sampled in the surroundings of the Krško NPP were already being performed in 1984 and continued until 1986 (Obelić et al. 1986, 1988). However, ${ }^{14} \mathrm{C}$ analyses were included in the regular radioactivity survey program in 1991 . Air is continuously sampled at the stack and ${ }^{14} \mathrm{C}$ in the form of $\mathrm{CO}_{2}$ and hydrocarbons is determined biweekly. In addition, air in several rooms in the plant was analyzed and ${ }^{14} \mathrm{C}$ from several trees was obtained.

\section{SAMPLING AND ANALYTICAL PROCEDURE}

Air is continuously sampled in a bypass of the main exhaust air stream in the stack at $115 \mathrm{~m}$ elevation by a differential $\mathrm{CO}_{2} / \mathrm{CH}_{4}$ sampler manufactured at the Institute of Isotopes at the Hungarian Academy of Science, Budapest (Hertelendi, Uchrin and Ormai 1989; Uchrin et al. 1992; Uchrin, Ormai and Hertelendi 1989; Veres et al. 1995). It consists of two parallel lines for air sampling. A single membrane pump maintains a continuous air flow at a rate of $2.5 \times 10^{-4} \mathrm{~m}^{3} \mathrm{~min}^{-1}$ through each of the lines. The air in the first line passes through a potassium hydroxide trap where $\mathrm{CO}_{2}$ is absorbed. In the second line, hydrocarbons are converted to $\mathrm{CO}_{2}$ on a Pd catalyst at $873 \mathrm{~K}$ and are passed through a second potassium hydroxide trap to absorb $\mathrm{CO}_{2}$ originating from hydrocarbons. Every two weeks the traps are replaced with new ones.

Absorbed $\mathrm{CO}_{2}$ was precipitated as $\mathrm{BaCO}_{3}$ by adding $\mathrm{BaCl}_{2}$ solution (Uchrin et al. 1993). We mixed $2 \mathrm{~g}$ of precipitate with $0.80 \mathrm{~g}$ of Cabosil M-5, and added $20 \mathrm{~cm}^{3}$ of Instagel scintillation cocktail to 
the scintillation vial. Beta activity was measured with a liquid scintillation analyzer (Packard Tricarb $^{\circledR}$ 2550TR A/B).

An identical sampler to that mentioned above was used and the same procedure followed also for ${ }^{14} \mathrm{C}$ analyses of air in selected rooms in the plant as requested by the Slovenian Nuclear Safety Administration in order to identify potential activities enhancing ${ }^{14} \mathrm{C}$ releases. Altogether, 18 analyses of two-week composite samples were made for the period April 1, 1994-January 3, 1995. Every two weeks, the sampler was moved to another place where elevated ${ }^{14} \mathrm{C}$ levels were expected. In some rooms the measurement was repeated. Among the places selected were the fuel handling building (FHB)-3 analyses, and the reactor containment at four elevations-3 analyses at $94 \mathrm{~m}$ above sea level (asl) (EL-94), 6 analyses at $100 \mathrm{~m}$ asl (EL-100), 2 analyses at $107 \mathrm{~m}$ asl (EL-107), and 4 analyses at $115 \mathrm{~m}$ asl (EL-115).

Three acacia trees (Robina sp.) were felled in a radius of a few kilometers from the plant stack at two locations. Based on the mean monthly dilution factors for individual directions and on the gamma dose rates as obtained by thermoluminiscent dosimeters, we determined the critical transport path for gas emissions to be in the east-northeastern (Sp. Stari grad) and northern directions (Vrbina) (2-3 $\mu \mathrm{Sv}$ compared to $0.1-0.6 \mu \mathrm{Sv}$ at other directions). Trees were selected with ages that covered the period since 1975. Samples were first combusted to $\mathrm{CO}_{2}$. The sample for $\delta^{13} \mathrm{C}$ mass spectrometric measurements was collected at this stage. $\mathrm{CO}_{2}$ was then reacted with hot lithium to form $\mathrm{Li}_{2} \mathrm{C}_{2}$. The addition of ${ }^{3} \mathrm{H}$-free water to the cooled lithium carbide produced acetylene, and then the acetylene was catalytically trimerized to benzene. A scintillator compound (butyl-PBD) was dissolved in benzene and the solution was then counted in a low-level liquid scintillator counter (LSC) (Quantulus LKB-Wallac) for $1000 \mathrm{~min}, 10$ times for each sample. Measurements were carried out at the Institute for Hydrology, GSF, Neuherberg, Germany.

\section{RESULTS AND DISCUSSION}

\section{Exhaust Air}

Figure 2 shows (A) biweekly averages of ${ }^{14} \mathrm{C}$ activity concentrations of $\mathrm{CO}_{2}$ in the exhaust air of the plant, (B) biweekly averages of ${ }^{14} \mathrm{C}$ activity concentrations of $\mathrm{CO}_{2}$ and hydrocarbons in the exhaust air of the plant and (C) electrical energy generation of Krško NPP. We see that our $\mathrm{CO}_{2} /$ hydrocarbons ratio is among the highest for the PWR-type plants (Kunz 1985; Winkelmann, Gesewsky and Schwibach 1984; Obelić et al. 1988; Trampuž 1989). We obtained the normalized release of 0.219 TBq GWe $\mathrm{e}^{-1} \mathrm{a}^{-1}$.

\section{Indoor Air}

Figure 3 presents the results of two-week average ${ }^{14} \mathrm{C}$ activity concentrations as $\mathrm{CO}_{2}$ and hydrocarbons in the selected rooms inside the Krško NPP. Generally, the values are below $5 \mathrm{~Bq} \mathrm{~m}^{-3}$ in the fuel handling building (FHB) and below $3.5 \mathrm{~Bq} \mathrm{~m}^{-3}$ in the reactor containment at elevation $94 \mathrm{~m}$ (EL-94). Values more than ten times as high were obtained in the containment at $107 \mathrm{~m}$ (EL-107) for June 1-July 1, 1994, and at $115 \mathrm{~m}$ (EL-115) for May 17-June 1, 1994 and December 1, 1994-January 3,1995 . Substantially higher ${ }^{14} \mathrm{C}$ levels of $1900 \mathrm{~Bq} \mathrm{~m}^{-3}$ were found in the containment at $100 \mathrm{~m}$ (EL-100) during July 1-16, 1994, and $190 \mathrm{~Bq} \mathrm{~m}^{-3}$ at $115 \mathrm{~m}$ (EL-115) for November 16-December 1, 1994. Unfortunately, the sampler failed in August, and since then only $\mathrm{CO}_{2}{ }^{14} \mathrm{C}$ has been measured. However, before that, the majority of ${ }^{14} \mathrm{C}$ activity in the rooms appeared as $\mathrm{CO}_{2}$.

Occasionally high indoor ${ }^{14} \mathrm{C}$ concentrations may be attributed to maintenance and other repair work in the plant. However, during the regular refit of the reactor in the period August 20-October 
5,1994 , when the reactor was shut down, no increased levels were observed. It should be pointed out that even the highest value of $1900 \mathrm{~Bq} \mathrm{~m}^{-3}$ is far below the limit for occupational exposure in

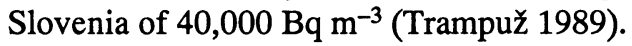

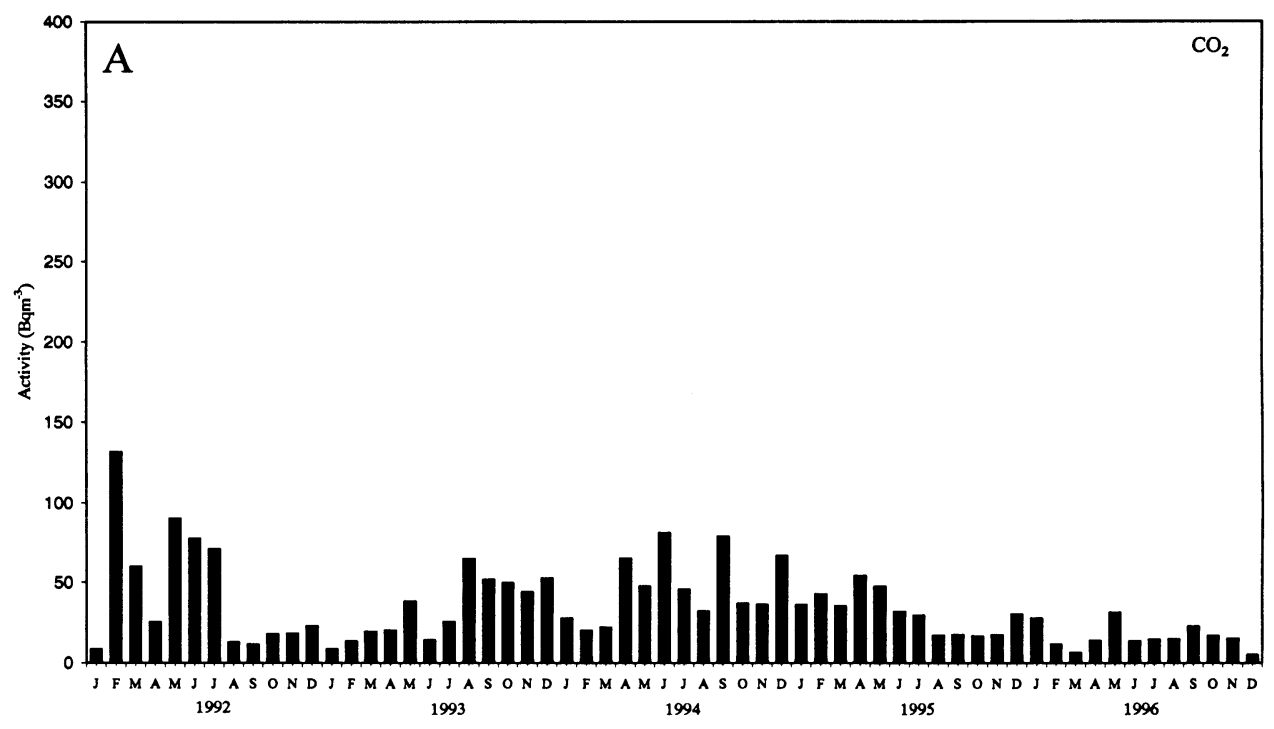

Fig. 2A. Biweekly averages of ${ }^{14} \mathrm{C}$ activity concentrations of $\mathrm{CO}_{2}$ in the exhaust air of the NPP

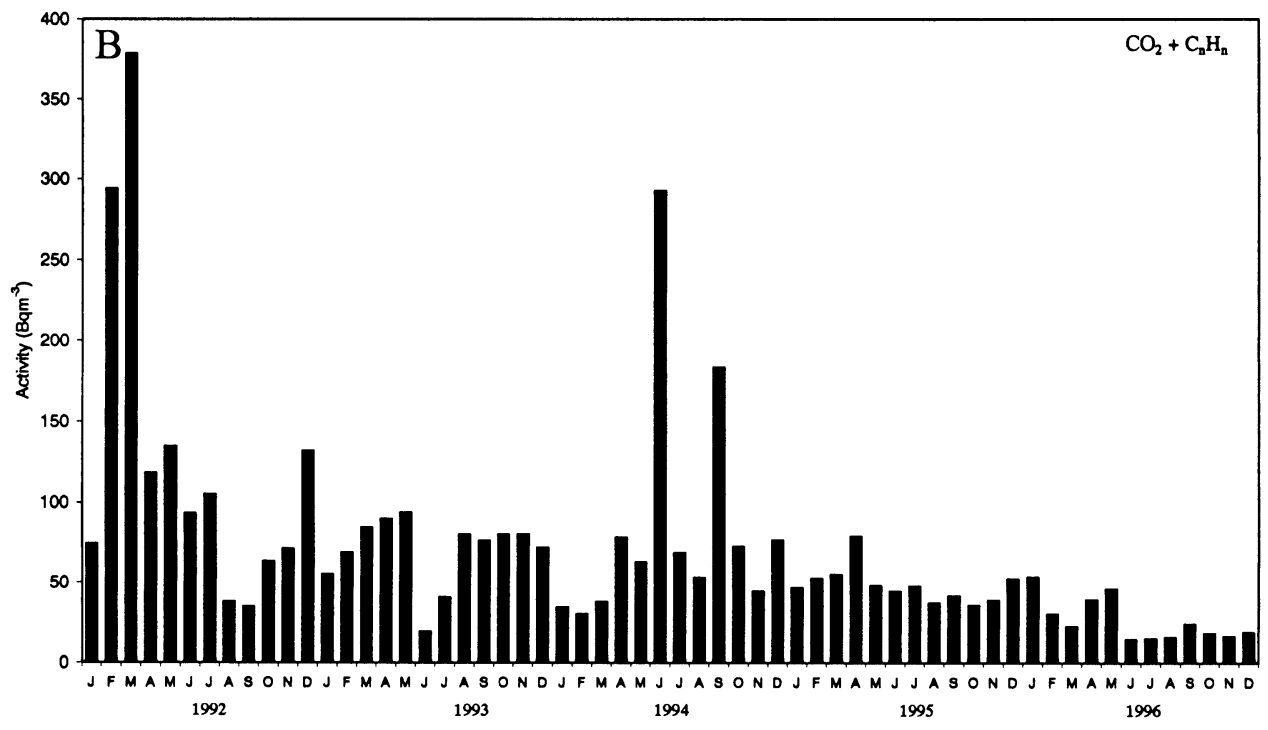

Fig. 2B. Biweekly averages of ${ }^{14} \mathrm{C}$ activity concentrations of $\mathrm{CO}_{2}$ and hydrocarbons in the exhaust air of the NPP 


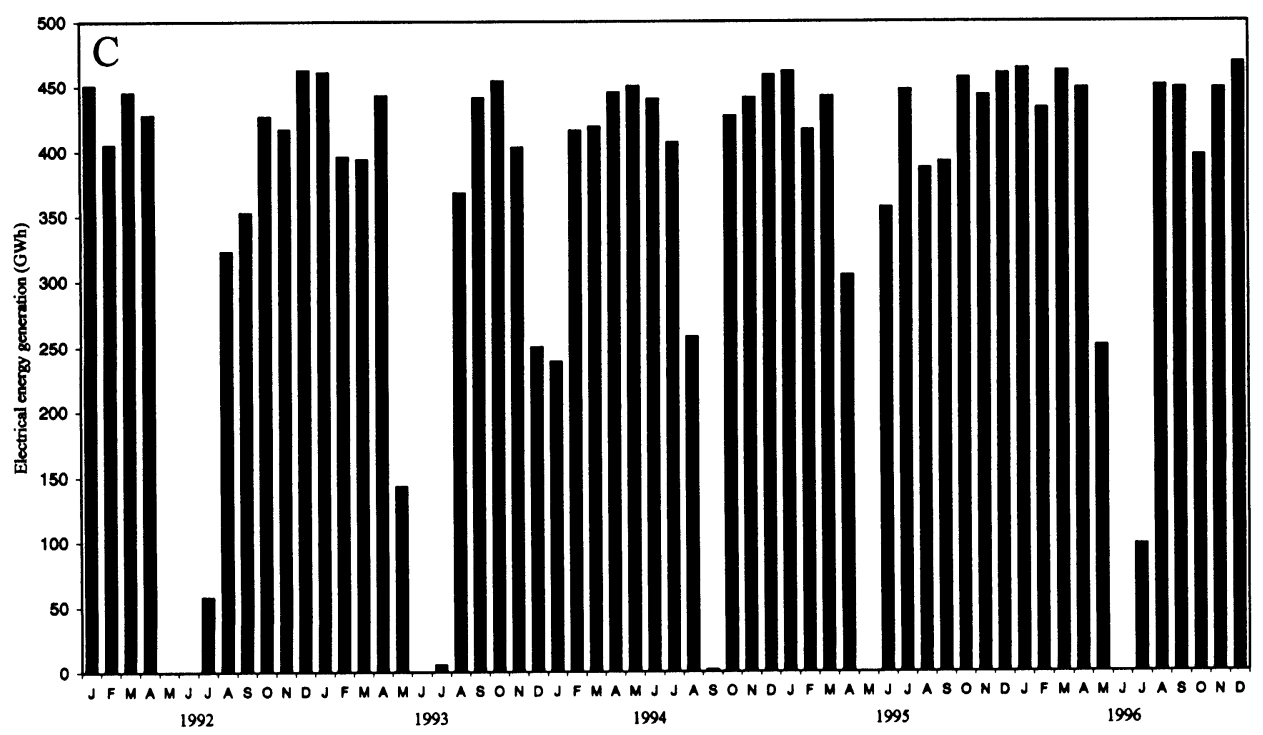

Fig. 2C. Electrical energy generation of Krško NPP

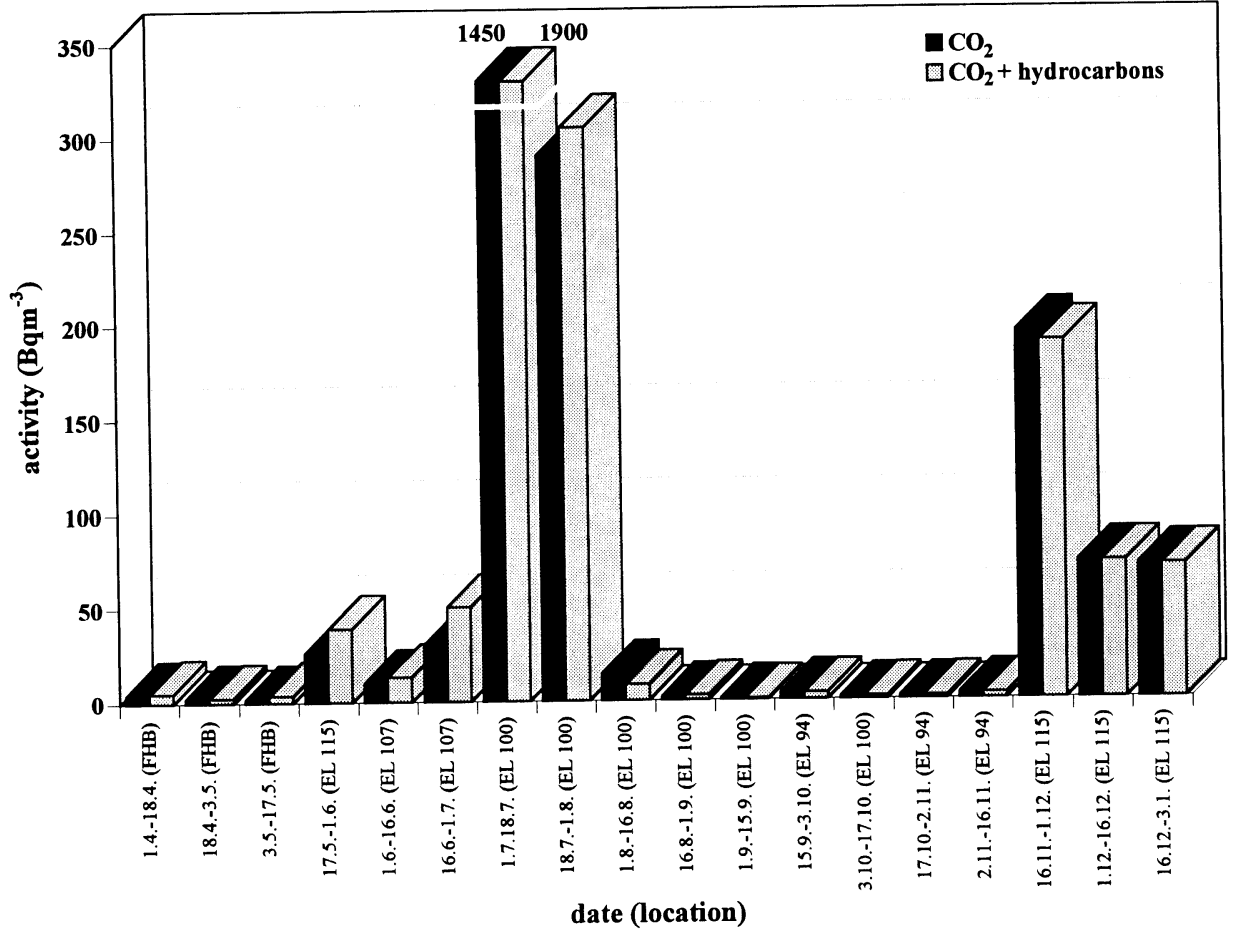

Fig. 3. Two-week average ${ }^{14} \mathrm{C}$ concentrations inside the Krško NPP 


\section{Tree Rings}

The results of ${ }^{14} \mathrm{C}$ activity in tree rings, expressed as a percentage of the modern standard (95\% of the National Institute of Standards and Technology (NIST) oxalic acid standard), are collected together with the $\delta^{13} \mathrm{C}$ values in Table 1. In Figure 4, the results are presented and compared with the previous results. The full line presents the mean clean air activity obtained (Levin and Kromer 1997). The mean atmospheric ${ }^{14} \mathrm{C}$ activity in Zagreb, according to Krajcar-Bronić (1998), is lower than the mean clean air activity for the Northern Hemisphere. Our results reflect slight enhancement only for sample 3, which may be attributed to the plant operation, which was expected (Uchrin et al. 1992). In the previous study mentioned above (Obelić et al. 1986, 1988), linden trees at Libna, $1.5 \mathrm{~km}$ away from the stack, and at Plitvice, $c a .150 \mathrm{~km}$ away from the plant, were analyzed.

TABLE $1 . \Delta^{14} \mathrm{C}$ Activity and $\delta^{13} \mathrm{C}$ Values in Tree Rings*

\begin{tabular}{|c|c|c|c|c|c|c|}
\hline \multirow[b]{2}{*}{ Year } & \multicolumn{2}{|c|}{ Sample 1} & \multicolumn{2}{|c|}{ Sample 2} & \multicolumn{2}{|c|}{ Sample 3} \\
\hline & $\Delta^{14} \mathrm{C}(\% \circ)$ & $\delta^{13} \mathrm{C}(\% 0)$ & $\Delta^{14} \mathrm{C}(\% 0)$ & $\delta^{13} \mathrm{C}(\% 0)$ & $\Delta^{14} \mathrm{C}(\%)$ & $\delta^{13} \mathrm{C}(\% 0)$ \\
\hline 1975 & & & 320 & -25.66 & & \\
\hline 1976 & & & 364 & -25.81 & & \\
\hline 1977 & & & 351 & -25.95 & & \\
\hline 1978 & & & 252 & -25.72 & & \\
\hline 1979 & 253 & -26.16 & 230 & -25.94 & & \\
\hline 1980 & & & 288 & -25.92 & & \\
\hline 1981 & & & 222 & -25.72 & & \\
\hline 1982 & & & 209 & -25.86 & & \\
\hline 1983 & & & 230 & -25.92 & & \\
\hline 1984 & & & 185 & -25.77 & 225 & -26.11 \\
\hline 1985 & & & & & 245 & -27.05 \\
\hline 1986 & & & 177 & -25.68 & 207 & -27.06 \\
\hline 1987 & & & & & 214 & -26.04 \\
\hline 1988 & & & & & 199 & -25.88 \\
\hline 1989 & & & & & 215 & -25.95 \\
\hline 1990 & & & 140 & -24.64 & 157 & -25.32 \\
\hline 1991 & & & & & 198 & -25.19 \\
\hline 1992 & & & & & 192 & -24.72 \\
\hline 1993 & & & & & 185 & -24.04 \\
\hline 1994 & 100 & -25.94 & 116 & -25.40 & 180 & -25.88 \\
\hline
\end{tabular}

${ }^{*}$ All $\Delta^{14} \mathrm{C}$ data $\pm 6 \%$ error. All $\delta^{13} \mathrm{C}$ data $\pm 0.05 \%$.

\section{CONCLUSION}

Within the regular radioactivity monitoring program at the Krško NPP, ${ }^{14} \mathrm{C}$ activity in the form of $\mathrm{CO}_{2}$ and hydrocarbons was determined in two-week air composite samples of the gaseous effluents. On average, $\mathrm{CO}_{2}$ contributes $c a .43 \%$ to the total ${ }^{14} \mathrm{C}$ activity. The normalized ${ }^{14} \mathrm{C}$ release for the period 1991-1996 was $0.219 \mathrm{TBqGWe}^{-1} \mathrm{a}^{-1}$, placing this plant below the world mean value for PWR.

Generally, in the rooms of the plant where elevated ${ }^{14} \mathrm{C}$ air concentrations might be expected, the values measured fell below $5 \mathrm{~Bq} \mathrm{~m}^{-3}$, with a few exceptions when they reached almost $2000 \mathrm{~Bq} \mathrm{~m}^{-3}$. But these high values are also far below the allowed levels for occupational exposure.

The analyses of tree rings showed considerable enhanced ${ }^{14} \mathrm{C}$ activity due to the plant operation at a distance of $1.5 \mathrm{~km}$ from either stack. 


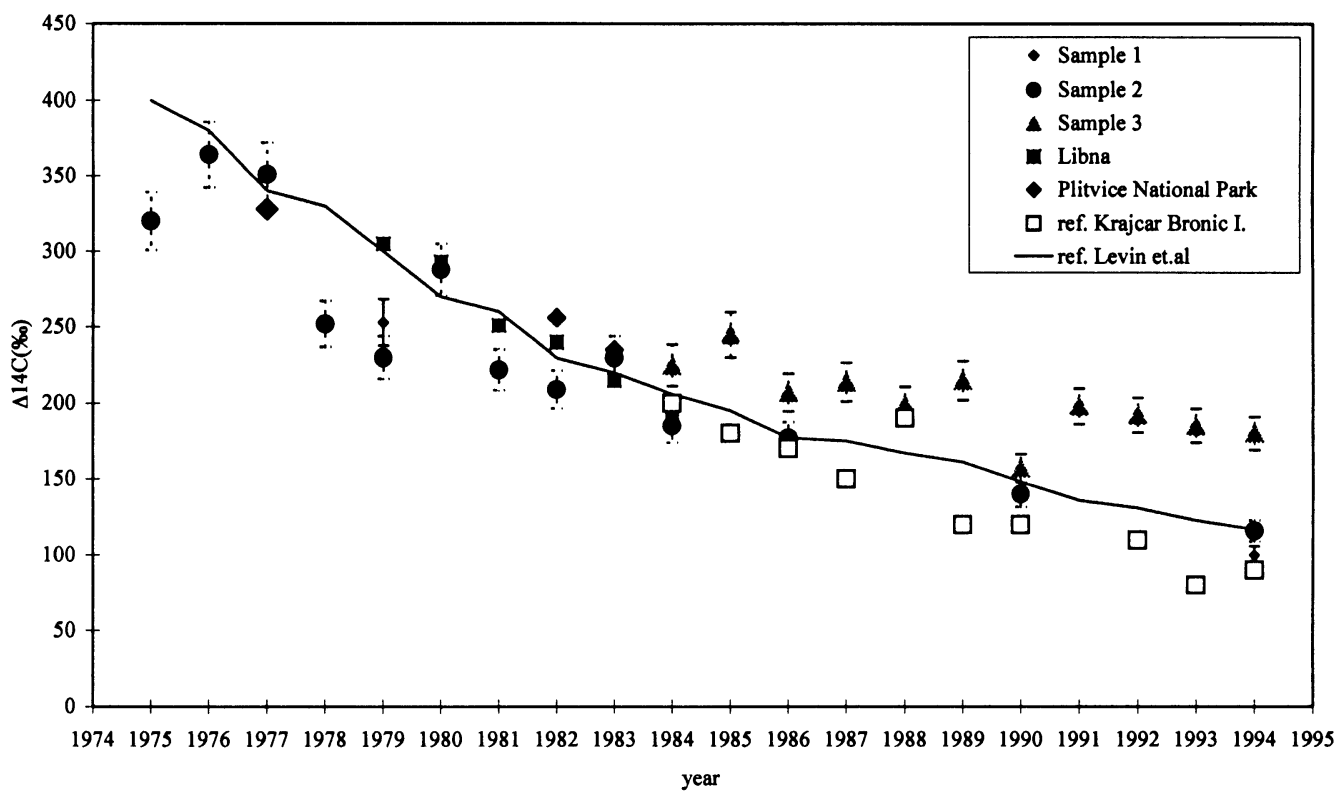

Fig. 4. $\Delta^{14} \mathrm{C}$ activity (\%o) of acacia tree rings, $1975-1994$, compared with ${ }^{14} \mathrm{C}$ activity of linden tree rings from Libna, the mean atmospheric ${ }^{14} \mathrm{C}$ activity in Zagreb according to Krajcar-Bronic (1998), and clean air activities obtained by Levin and Kromer (1997).

\section{ACKNOWLEDGMENTS}

The authors wish to thank to Mr. T. Mohar and Mr. J. Novak for taking care of the samples, and Mrs. $\breve{S}$. Fedina and Mrs. J. Burger for sample preparation and counting. We are grateful to Dr. E. Hertelendi and Dr. U. Miklavžič for their helpful comments. We very much appreciate the opportunity to analyze tree-ring samples at the Institute for Hydrology, GSF, Neuherberg, Germany. We also acknowledge the financial support of the Slovenian Nuclear Safety Administration.

\section{REFERENCES}

Belan, T., Chudy, M., Durana, L., Grgula, M., Holy, K., Levailova, D., Provinec, P., Richtarikova, M. and Šivo, A. 1990 Investigation of radionuclide variations in the Bratislava air. In Proceedings of the 14th Europhysics Conference on Nuclear Physics, Rare Nuclear Processes, Bratislava, Czecho-Slovakia 22-26 October 1990: 345-366.

Csongor, E. and Hertelendi, E. 1982 Fission products and radiocarbon as environmental pollutant due to atmospheric nuclear weapon tests measured in Debrecen since 1992. ATOMKI Közlemények 3: 179-183.

Fairhall, A.W. and Young, J.A. 1970 Radionuclides in the Environment. Advances in Chemistry Series 93. Washington, D.C., American Chemical Society: 529 p.

Hayes, D. W. and MacMurdo, K. W. 1977 Carbon-14 production by the nuclear industry. Health Physics 32(4): 215-219.

Hertelendi, E. and Csongor, E. 1982 Antrophogenic ${ }^{14} \mathrm{C}$ excess in the troposphere between 1951 and 1978 measured in tree rings. Radiochemical and Radioana lytical letters 56(2): 103-110.

Hertelendi, E., Uchrin, G. and Ormai, P. $1989{ }^{14}$ C release in various chemical forms with gaseous effluents from the Paks Nuclear Power Plant. In Long, A., Kra, R. S. and Srdoc, D., eds., Proceedings of the 13th International ${ }^{14} \mathrm{C}$ Conference. Radiocarbon 31(3): 754-761.

Krajcar-Bronić, I., Horvatinžic, N. and Obelič, B. 1998 Two decades of environmental isotope records in Croatia: Reconstruction of the past and prediction of future levels. In Mook, W. and van der Plicht, J., eds., Proceedings of the 16 th International ${ }^{14} \mathrm{C}$ Conference. Radiocarbon 40: in press.

Kunz, C. O. 1985 Carbon-14 discharge at the three lightwater reactors. Health Physics 49: 25-35.

Levin, I., Kromer, B., Barabas, M. and Münnich, K. O. 1988 Environmental distribution and long-term dispersion of reactor ${ }^{14} \mathrm{CO}_{2}$ around two German nuclear power plants. Health Physics 54(2): 149-156. 
Levin, I. and Kromer, B. 1997 Twenty years of atmospheric ${ }^{14} \mathrm{CO}_{2}$ observations at Schauinsland Station, Germany. Radiocarbon 39(2): 205-218.

Levin, I, Münnich, K. O. and Weiss, W. 1980 The effect of anthropogenic $\mathrm{CO}_{2}$ and ${ }^{14} \mathrm{C}$ sources on the distribution of ${ }^{14} \mathrm{C}$ in the atmosphere. In Stuiver, M. and Kra, R. S., eds., Proceedings of the 10 th International ${ }^{14} \mathrm{C}$ Conference. Radiocarbon 22(2): 379-390.

McCartney, M., Baxter M. S. and McKay, K. 1986 Global and local effects of ${ }^{14} \mathrm{C}$ discharges from the nuclear fuel cycle. In Stuiver, M. and Kra, R. S., eds., Proceedings of the 13 th International ${ }^{14} \mathrm{C}$ Conference. Radiocarbon 28(2A): 634-643.

McCartney, M., Baxter, M. S. and Scott E. M. 1988a Carbon-14 Discharges from the nuclear fuel cycle: 1 . Global effects. Journal of Environmental Radioactivity 8: 143-155.

1988b Carbon-14 discharges from the nuclear fuel cycle: 2. Local effects. Journal of Environmental Radioactivity 8: 157-171.

Obelić, B., Krajcar-Bronić, I., Srdoč, D. and Horvatinčić, N. 1986 Environmental ${ }^{14} \mathrm{C}$ levels around the 632MWe nuclear power plant Krško in Yugoslavia. In Stuiver, M. and Kra, R. eds., Proceedings of the 12 th International ${ }^{14} \mathrm{C}$ Conference. Radiocarbon $28(2 \mathrm{~A})$ : 644-648.

1988 Monitoring of the ${ }^{14} \mathrm{C}$ activity in the environment of the nuclear power plant Krsko in Yugoslavia. In Twenty Years Experience in Radiation Protection: A Review and Outlook. Proceedings of the 4th European Congress and 13th Regional Congress of IRPA, 15-19 September 1986, Salzburg, Austria. Seibersdorf, OVS.

Otlet, R. L., Fulker, M. J. and Walker, A. J. 1992 Environmental impact of atmospheric carbon-14 emissions resulting from the nuclear energy cycle. In Taylor, $\mathbf{R}$. E., Long, A. and Kra, R. S., eds., Radiocarbon After Four Decades. New York, Springer-Verlag: 519-534.

Raaen, V. F., Ropp, G. A. and Raaen, H. P. 1968 Carbon14. New York, McGraw-Hill: $388 \mathrm{p}$.

Segl, M., Levin, I., Schoch-Fischer, H., Münnich, M., Kromer, B., Tschiersch, J. and Münnich, K. O. 1983 Anthropogenic ${ }^{14} \mathrm{C}$ variations. Radiocarbon $25(2)$ : 583-592.

Trampuž, M. 1989 Radiation Protection. Ljubljana, Institute of Occupational Safety. (In Slovenian).
Uchrin, G., Csaba, E., Hertelendi, E., Ormai, P. and Barnabas, I. $1992{ }^{14} \mathrm{C}$ releases from a Soviet designed pressurized water reactor nuclear power plant. Health Physics 63(6): 651-655.

Uchrin, G., Csaba, E., Volent, G., Chyly, P., Slavik, O., Miklavžiz, U., Kobal, I. and Mohar, T. 1993 Carbon14 measurements at three PWR type nuclear power plants. Proceedings of Austrian-Italian-Hungarian Radiation Protection Symposium with the Radiation Protection Association of Slovenia and the Croatian Radiation Protection Association, Radiation Protection in Neighbouring Countries in Central Europe, Obergurgel-Tyrol, 1993.

Uchrin, G., Ormai, P. and Hertelendi, E. 1989 Local and global impact of tritium and carbon-14 released from Paks Nuclear Power Plant. In Minkovic, M. M., Pavlovic, R. S. and Raicevic, J. J., eds., Proceedings of the 30th Anniversary Symposium of Radiation Protection in the Boris Kidrix Institute of Nuclear Science. Radiation Protection Selected Topics. Beograd, Boris Kidrił Inst.: 358.

Veres, M., Hertelendi, E., Uchrin, Gy., Csaba, E., Barnabás, E., Ormai, P., Volent, G. and Futó, I. 1995 Concentration of radiocarbon and its chemical forms in gaseous effluents, environmental air, nuclear waste and primary water of a pressurized water reactor power plant in Hungary. In Cook, G. T., Harkness, D. D., Miller, B. F. and Scott, E. M., eds., Proceedings of the 15 th International ${ }^{14} \mathrm{C}$ Conference. Radiocarbon 37(2): 497-504.

Wahlen, M. and Kunz, C. O. $1978{ }^{14} \mathrm{C}$ activity and distribution in gaseous effluents from pressurized water reactors. Transactions of the American Nuclear Society 30: 113-114.

Wallace, D., Jr. 1979 Carbon-14 production in nuclear reactors. In Carter, M. W., Moghissi, A. A. and Kahn, B., Management of Low-Level Radioactive Waste. Vol. 1. New York, Pergamon Press: 151-191.

Winkelmann, I., Gesewsky, P. and Schwibach, J. 1984 Measurements of Carbon- 14 released with the gaseous effluent from nuclear facilities in the Federal Republic of Germany. In Proceedings of the Second IAEA Research Co-ordination Meeting on Carbon-14 from Nuclear Facilities, 10-14 December 1984, Bombay, India. 